\title{
PERAN PENELITIAN HUKUM YANG DILAKSANAKAN OLEH ORGANISASI \\ BANTUAN HUKUM DALAM MENDUKUNG PEMBANGUNAN HUKUM
}

(The Role of Legal Research Implemented by Legal Aid Organization to Support Law Development)

\author{
Marulak Pardede \\ Pusat Penelitian dan Pengembangan Sistem Hukum Nasional \\ Badan Pembinaan Hukum Nasional \\ Jl. Mayjen Sutoyo No. 10 Cililitan Jakarta Timur \\ Email: marulakp@yahoo.com
}

Naskah diterima: 11 April 2013; revisi: 13 April 2013; disetujui: 15 April 2013

\begin{abstract}
Abstrak
Salah satu program kegiatan lain yang merupakan hak dari Organisasi Bantuan Hukum berdasarkan Pasal 9C UndangUndang No. 16 Tahun 2011 adalah kegiatan penelitian hukum sehubungan dengan pelaksanaan bantuan hukum. Tulisan ini membahas bagaimanakah peran penelitian hukum yang dilaksanakan oleh Organisasi Bantuan Hukum dalam mendukung pembangunan hukum. Dengan menggunakan pendekatan bersifat yuridis normatif serta metode analisis data kualitatif (deskriptif-analitis) terlihat bahwa peranan penelitian hukum yang dilakukan oleh Organisasi Bantuan Hukum, sangat penting dalam mendukung pembangunan sistem hukum nasional, untuk mengungkapkan data ilmiah yang menyangkut aspek-aspek filosofis, yuridis, sosiologi, ekonomi, maupun politik yang dapat mempengaruhi perkembangan hukum sebagai bahan kebijaksanaan pembangunan hukum, karena banyak hasil-hasil penelitian hukum yang dilakukan oleh berbagai lembaga penelitian hukum di daerah, tidak sepenuhnya terakumulasi dalam penentuan kebijakan hukum di pusat sesuai dengan semangat otonomi daerah. Untuk itu, dalam pelaksanaan bantuan hukum perlu dikembangkan penelitian terapan yang normatif dan interdisipliner dalam mendukung penetapan kebijakan dan pengambilan keputusan dalam rangka pelaksanaan bantuan hukum dan pembangunan hukum nasional, serta penyempurnaan dan pemantapan kerja sama penelitian dan pengembangan hukum dengan berbagai instansi termasuk Organisasi Bantuan Hukum dan perguruan tinggi serta lembaga penelitian nasional, maupun internasional.
\end{abstract}

Kata kunci: penelitian hukum, organisasi bantuan hukum, pembangunan hukum

\section{Abstract}

One of other activities program which is rights of legal aid organization based on Article 9C, Law Number 16 Year 2011 is law research in concerning with law aid implementation. this paper discusses about how the role of legal research which implemented by legal aid organization in support of law development. by using juridical normative approach well as qualitative data analysis shows that the role of legal research which conducted by legal aid organization, important in support the national law system development, to reveal scientific data concerning philosophical aspects, juridical, sociology, economics and politics could be influencing law development as law policies, as many result of legal research which implemented by legal research institution in region, not entirely accumulated in law policies making center in according to regional autonomy spirit. for it, the implementation of legal aid needs to be of applied normative research and interdisciplinary in supporting policy setting and decision making in the implementation of legal aid and national law development, as well as improving and strengthening of research cooperation and law development with others institution, including organization on law aid, university, national research institution and international.

Keywords: legal research, legal aid organization, legal development 


\section{A. Pendahuluan}

Pembentukan suatu peraturan perundangundangan yang tidak dilandasi dengan suatu perencanaan dan penelitian yang matang, diyakini tidak akan mampu bertahan lama dan tidak mampu menjawab perubahan zaman. Pembangunan hukum akhir-akhir ini dirasakan semakin tidak lagi dititikberatkan pada langkah strategis dalam meningkatkanakselerasi reformasi hukum yang mencakup materi atau substansi hukum baik yang tertulis maupun tidak tertulis (legal substance), struktur atau kelembagaan hukum yang juga mencakup aparatur hukum (legal structure) dan budaya hukum, legal culture. Dalam perkembangannya saat ini pembangunan hukum dirasakan semakin berorientasi kepada kepentingan sesaat (jangka pendek) masingmasing kelompok, golongan, partai politik, dan berbagai kepentingan lainnya.

Sejalan dengan kebijakan pembangunan hukum ini ada hal yang patut diperhatikan, yaitu apa yang dikatakan oleh Gunther Teubner, ${ }^{1}$ "Substantive and Reflexive Elements in Modern Law", Law and Society Review, bahwa: "Legal development is not identified exclusively with the unfolding of norms, principles, and basic concepts of law. Rather, it is determined by the dynamic interplay of social forces, institutional constraints, organizational structures, and last but not least-conceptual potentials". Pembangunan hukum bukan sekedar pembangunan atau pembaruan materi atau substansi hukumnya semata-mata, melainkan merupakan pembaharuan orientasi dan nilai yang melandasi aturan hukum termasuk juga elemen terkait lainnya, yakni struktur hukum dan budaya hokum, karena aturan tersebut perlu dilaksanakan dan ditegakkan sebaik-baiknya oleh segenap aparat hukum, didukung oleh sarana dan prasarana hukum yang memadai dan juga ditaati oleh masyarakat yang memiliki kesadaran hukum yang tinggi.

Dengan diundangkannya Undang-Undang Nomor 12 Tahun 2011 tentang Pembentukan Peraturan Perundang-undangan, diharapkan akan mengakhiri maraknya gugatan perundangundangan yang diajukan oleh berbagai kalangan masyarakat kepada Mahkamah Konstitusi. Pengajuan gugatan ke Makhamah konsitusi, merupakan pertanda bahwa terdapat ketidakberesan dalam penyusunan suatu Undang-Undang yang dilakukan oleh DPR bersama Pemerintah. Gugatan tersebut mengemuka sehubungan dengan telah terjadinya ketidak sinkronan, ketidakselarasan antara undang-undang dengan UUD 1945. Menjadi persoalan, mengapa masalah tersebut sampai terjadi? Apakah yang dilakukan oleh DPR bersama Pemerintah telah memenuhi asas-asas hukum mengenai pembentukan suatu peraturan perundang-undangan? Berbagai perundangundangan baru saja dilahirkan, akan tetapi sudah harus disempurnakan kembali? Apakah proses penyusunan perundang-undangan tersebut telah didahului dengan suatu penelitian hukum? Bagaimanakah tanggungjawab pembuat Undang-Undang, apabila hasil pekerjaannya dianulir oleh Makhamah Konstitusi?

Pertimbangan dan latar belakang pembuatan suatu undang-undang, sangat kental dipengaruhi oleh muatan politis pada saat dibuatnya, yaitu hukum dipakai sebagai alat untuk mengabsahkan

\footnotetext{
Gunther Teubner, Substantive and Reflexive Elements in Modern Law, Law and Society Review (London Press, 1983), hlm. 156-158.

2 John Henry Marryman, The Civil Law Tradition (Standford: California Press, 1969), hlm. 1-8.
} 
tindakan.John HenryMarryaman mengemukakan bahwa strategi pembangunan hukum yang ortodoks berciri adanya peranan yang sangat dominan dari pemerintah dan parlemen, dalam menentukan arah perkembangan hukum. Hukum yang dihasilkan seperti ini bersifat positivisinstrumentalis. $^{2}$

Dengan diundangkannya Undang-Undang Nomor 16 Tahun 2011 tentang Bantuan Hukum, maka Negara Republik Indonesia dengan tegas menjamin hak konstitusional setiap orang untuk mendapatkan pengakuan, jaminan, perlindungan, dan kepastian hukum yang adil serta perlakuan yang sama di hadapan hukum sebagai sarana perlindungan hak asasi manusia. Negara juga bertanggung jawab terhadap pemberian bantuan hukum bagi orang miskin sebagai perwujudan akses terhadap keadilan. Disamping itu, pengaturan mengenai bantuan hukum yang diselenggarakan oleh negara harus berorientasi pada terwujudnya perubahan sosial yang berkeadilan. ${ }^{3}$

Menyoroti salah satu program kegiatan lain yang merupakan hak dari Organisasi Bantuan hukum, adalah masalah kegiatan penelitian hukum. Masalah ini dipandang cukup menarik, mengingat fungsi dan tugas Organisasi Bantuan Hukum selama ini sebagaimana dituangkan di dalam berbagai peraturan perundangundangan, adalah memberikan bantuan hukum terhadap masyarakat yang membutuhkan jasa pengacara maupun advokat. Namun dengan diundangkannya Undang-Undang Nomor 16 Tahun 2011 tentang Bantuan Hukum ini, pemberi bantuan hukum, dalam hal ini Organisasi Bantuan Hukum, diberikan hak untuk melakukan kegiatan penelitian hukum, yang tentunya dalam kaitannya dengan penyelenggaraan bantuan hukum itu sendiri, dalam arti sempit dan pembangunan hukum nasional dalam arti luas. Hal ini menimbulkan pertanyaan, tentang peran penelitian hukum yang dilaksanakan oleh Organisasi Bantuan Hukum dalam mendukung pembangunan hukum sebagai implementasi Pasal 9c Undang-Undang dimaksud.

\section{B. Permasalahan}

Berdasarkan uraian tersebut di atas, maka permasalahan yang diteliti dalam penelitian ini, dapat dikemukakan sebagai berikut, yaitu:

1. Mengapa penelitian hukum sangat berperan penting didalam pembentukan peraturan perundang-undangan, serta pembangunan hukum pada umumnya?

2. Bagaimanakah peran penelitian hukum yang dilaksanakan oleh Organisasi Bantuan Hukum dalam mendukung pelaksanaan pembangunan hukum?

\section{Metode Penelitian}

Metode penelitian yang dipergunakan dalam pelaksanaan penelitian ini, dikemukakan sebagai berikut :

3 Undang-Undang Republik Indonesia Nomor 16 Tahun 2011 Tentang Bantuan Hukum, Pasal 25 menegaskan, Undang-Undang ini mulai berlaku pada tanggal diundangkan. Agar setiap orang mengetahuinya, memerintahkan pengundangan Undang-Undang ini dengan penempatannya dalam Lembaran Negara Republik Indonesia. Disahkan Di Jakarta, Pada tanggal 31 Oktober 2011. Diundangkan Di Jakarta, Pada tanggal 2 November 2011. Lembaran Negara Republik Indonesia Tahun 2011 Nomor 104. Tambahan Lembaran Negara Republik Indonesia Nomor 5248.

4 Soerjono Soekanto dan Sri Mamudji, Penelitian Hukum Normatif Suatu Tinjauan Singkat (Jakarta: CV. Rajawali, 1985), hlm. 15 . 


\section{Metode Pendekatan}

Metode pendekatan yang dipergunakan dalam pelaksanaan penelitian ini adalah bersifat yuridis normatif.

\section{Spesifikasi Penelitian}

Sejalan dengan maksud dan tujuan penelitian yang ingin dicapai, maka tipe penelitian ini adalah deskriptif, yaitu memberikan gambaran (deskripsi) secermat mungkin mengenai obyek penelitian dengan pemilihan bahan yang representatif. Tipe perencanaan penelitian adalah penelitian hukum normatif, dalam pengertian sebagaimana dimasudkan oleh Soerjono Soekanto dan Sri Mamuji, yaitu penelitian yang meliputi asas-asas hukum, sinkronisasi hukum dan perbandingan hukum. ${ }^{4}$

\section{Bahan Penelitian}

Adapun bahan-bahan penelitian yang dipergunakan dalam penelitian ini adalah:

a. Bahan Primer, yang mencakup peraturan perundang-undangan yang berlaku, yurisprudensi yang berkaitan dengan pokok permasalahan penelitian;

b. Bahan Sekunder, terdiri dari hasil-hasil penelitian yang telah ada sebelumnya yang terkait dengan permasalahan penelitian; kepustakaan, termasuk bahan dan hasil seminar dan konferensi-konferensi serta ulasan mass-media, termasuk ulasan dalam majalah hukum, majalah populer dan surat kabar yang berkaitan dengan objek penelitian;

c. Bahan Tersier, yang terdiri dari Kamus Hukum, Ensiklopedi dan Kamus Pendukung lainnya.

4. Alat Penelitian yang dipergunakan dalam penelitian ini adalah:

a. Studi kepustakaan/normatif (Library Studies), yaitu mempelajari berbagai literatur yang berhubungan dengan objek penelitian, termasuk penelitian normatif mengenai peraturan perundang-undangan yang berhubungan dengan penelitian.

b. Studi Dokumen (Documentary Studies) dari bahan primer dan sekunder.

5. Metode Analisis Data.

Metode analisis data yang dipergunakan dalam penelitian ini adalah kualitatif. Data yang berupa angka sedapat mungkin disajikan dalam bentuk kualitatif. Sifat dan Bentuk Laporan penelitian ini, adalah deskriptif-analitis.

\section{Pembahasan}

\section{Peran Penelitian Hukum Dalam Strategi Pembangunan Hukum}

Penelitian hukum merupakan penilaian, penelaahan terhadap tingkah laku yang disebut hukum, yaitu mengenai pengertian-pengertian yang benar, mengenai keterpaduannya secara logis sebagai suatu sistem yang bebas dari pertentangan-pertentangan di dalam dirinya. Hukum selalu sarat dengan nilai-nilai tertentu. Apabila berbicara tentang nilai, maka disitu telah masuk kegiatan menilai dan memilih. Keadaan yang demikian inilah yang memberikan arah tertentu kepada jalannya hukum disuatu negara. Sejak kedudukan negara dalam artian modern semakin kokoh, maka peranan hukum semakin penting, yaitu sebagai sarana untuk mengimplementasikan keputusan-keputusan negara. Proses penegakan hukum pada suatu masa dapat berbeda karena perkembangan masyarakatnya. Dalam masa reformasi politik mengalami perubahan yang berakibat hukum pun perlu diubah, karena hukum dibentuk sesuai dengan kemauan politik hukum suatu negara. Apabila tatanan politik suatu negara 
mantap akan berakibat hukum bersifat otonom. ${ }^{5}$ Hukum di negara berkembang menurut Nonet dan Selznick, bahwa pada waktu suatu negara mengalami kemerdekaan, maka hal yang harus dibenahi adalah penyusunan tatanan kehidupan sosial, ekonomi dan politik secara baik. Selama aspek tersebut masih perlu ditata, maka hukum pun akan sering mengalami perubahan, sesuai keinginan penguasa. ${ }^{6}$

Kondisi tersebut diatas mengakibatkan pemahaman masyarakat terhadap penegakan hukum dalam era reformasi ini, semakin menimbulkan kebingungan karena beraneka ragamnya pendapat yang dilontarkan oleh berbagai kalangan yang mengaku dirinya pakar (ahli) di bidang hukum terhadap masalah hukum yang sedang berkembang. Disatu sisi ada yang mengemukakan pendapat, namun di sisi lain ada yang menyangkal. Hal ini sangat tentu membingungkan masyarakat awam, untuk mengetahui pendapat mana yang benar dan harus diturut, terutama karena secara gamblang disebarluaskan oleh media massa surat kabar maupun elektronika. Misalnya, acara-acara aneka dialog, diskusi terbatas, derap hukum, dan berbagai acara lainnya mengenai persoalan hukum.

Kondisi ini telah melahirkan kesimpangsiuran pengertian hukum di kalangan masyarakat. Akhir-akhir ini berbagai perundang-undangan dirasakan masih dihadapkan kepada berbagai kendala, antara lain: terjadi perbedaan penafsiran diantara sesama aparatur penegak hukum, Organisasi Bantuan Hukum (praktisi/ pengacara), teoritisi; perbenturan kepentingan; dis-sinkronisasi antar perundang-undangan; dan ketidak jelasan isi peraturan itu sendiri. Keadaan ini tentu menimbulkan kecemasan bagi masa depan pembangunan hukum, sehingga politicalwill pemerintah dipandang sangat perlu untuk menegakkan kembali supremasi hukum seiring dengan bergulirnya era reformasi hukum; era globalisasi serta keinginan yang cukup kuat dari berbagai daerah untuk mewujudkan otonomi daerah.

Menilik pelaksanaan pembangunan dan penegakan hukum di Indonesia yang telah terlaksana selama lebih dari kurun waktu setengah abad, tampaknya makin amburadul. Alih-alih mengharapkan meningkatnya kesadaran hukum masyarakat, kenyataannya justru menghasilkan sebaliknya, profil masyarakat makin bringas, koruptor semakin merajalela, mafia hukum dimana-mana, penyalahgunaan wewenang semakin semenamena, serta tindakan main hakim sendiri semakin meruyak. Pembangunan hukum tidak berjalan sesuai dengan harapan akan fungsi dan peranan hukum dalam membawa perubahan sikap masyarakat secara menyeluruh. Kondisi ini boleh dikatakan terjadi pada keseluruhan aspek pembangunan hukum, mulai dari proses pembentukan peraturan perundang-undangan sampai kepada penegakan hukum.

Hukum menjadi alat untuk melaksanakan ideologi dan program negara. Strategi pembangunan hukum ortodoks mengandung ciri sistem civil Law/tradisi hukum kontinental), dan socialist law (hukum sosialis), dimana peranan pengusaha/pemerintah dan parlemen sangat berpengaruh. Pada abad ke-12, di Inggris, pembangunan hukum responsif dimana pada

Myrda, Penelitian Terhadap Hukum Negara Berkembang (Jakarta: Pradnya Paramita, 1971), hlm. 219-220.

$6 \quad$ Nonet \& Selznick, Law and Society in Trantition (New York: Harper Colophon Books, 1978), hlm. 25. 
akhirnya hukum adat mempunyai posisi yang kuat. $^{7}$

Timbulnya keraguan terhadap keberadaan hukum, karena keadilan yang merupakan salah satu prinsip utama dari hukum, tidak terpenuhi. Prinsip keadilan tidak pernah berubah, keadilan yang dirumuskan para filsuf secara berbedabeda, namun tujuannya adalah agar tercapai keseimbangan dalam penerapannya, yaitu keseimbangan antara nilai-nilai secara ideal dan kenyataan dimana hukum dioperasikan. Aristoteles memberikan pendapat tentang keadilan, bahwa keadilan ada dimana-mana, dan tidak lahir karena pemikiran, dan bersifat in-different, tetapi apabila keadilan ditetapkan, maka akan berakibat adanya tanggung jawab, seperti sanksi dalam suatu pelanggaran norma. ${ }^{8}$

Pada abad pertengahan, Thomas Aquino mengemukakan, bahwa keadilan adalah pertentangan antara hukum sorgawi dan duniawi, yang dinyatakan dalam pertentangan antara akal pikiran dan tatanan dan ketertiban yang dipaksakan sesuai dengan pikiran Hugo Grotius dan Rousseau. Abad keduapuluhan bangkit kembali pemikiran hukum alam sebagai akibat pada abad kesembilanbelas orang mengandalkan pemikiran secara empiris. ${ }^{9}$ Timbulnya pemikiran empiris terlihat dalam kehidupan hukum di negara modern, seperti Eropa, USA sebagai negara industri maju, karena dinamika kehidupannya relatif stabil dan terkendali. Nilainilai yang mendasari pemikiran tentang keadilan akan timbul kembali apabila manusia mengalami tekanan, seperti krisis di Indonesia akibat perubahan politik tuntutan reformasi.

Di dalam sejarah penyusunan konstitusi dimaksudkan untuk menentukan batas wewenang penguasa dan mengatur jalannya pemerintahan, dalam perkembangannya tidak lagi hanya memuat aturan hukum, melainkan juga merumuskan prinsip-prinsip hukum, haluan negara, dan patokan kebijaksanaan yang kesemuanya mengikat penguasa. Sir Ivor Jennings dalam bukunya The Cabinet Government, ${ }^{10}$ menerangkan prinsip-prinsip konstitusi: "Practices turn into conventions and precedents create rules because they are consistent with and are implied in the principles of the constitutions. Of these, there are four of major improtance. The British Constituions is democratic; it is parliamentary; it it monarchical; and it is a cabinet system".

Disamping itu, menurut Lord Bryce sebagaimana dikutip oleh C.F.Strong dalam bukunya Modern Political Constitutions, ${ }^{11}$ merumuskan konstitusi sebagai: "A frame of political society, organised through and by law, that is to say, one in which law has established permanent institutions with recognised functions definite rights". Konstitusi dibuat dan diubah untuk menjamin hak-hak rakyat untuk mengendalikan tingkah laku penguasa, mencegah perbuatan sewenang-wenang. Pemerintah dalam arti luas harus mempunyai kekuasaan perundang-undangan (Legislative power), kekuasaan pelaksanaan (Executive 
power), dan kekuasaan peradilan (Judicial power).

Salah satu pasal undang-undang dimaksud yang berkaitan dengan pembinaan dan pembangunan hukum, sangat perlu disimak dan dikaji lebih mendalam adalah ketentuan Pasal 9, yang antara lain menegaskan, bahwa Pemberi Bantuan Hukum berhak: (c) menyelenggarakan penyuluhan hukum, konsultasi hukum, dan program kegiatan lain yang berkaitan dengan penyelenggaraan Bantuan Hukum. Di dalam penjelasan Pasal 9 huruf (c), dijelaskan, bahwa yang dimaksud dengan "program kegiatan lain yang berkaitan dengan penyelenggaraan Bantuan Hukum" adalah program: investigasi kasus, pendokumentasian hukum, penelitian hukum, mediasi, negosiasi, dan pemberdayaan masyarakat.

Era reformasi yang dewasa ini sedang dijalani oleh bangsa dan Negara Republik Indonesia, telah memberikan peluang bagi proses transformasi atau perubahan struktural disegala bidang. $\mathrm{Hal}$ tersebut ditandai dengan bergulirnya proses demokratisasi yang semakin tumbuh dan berkembang, pemberdayaan dan partisipasi masyarakat dalam berbagai bidang, penegakan supremasi hukum dan pemberantasan korupsi, kolusi dan nepotisme serta penghormatan hak-hak asasi manusia.. ${ }^{12}$ Namun demikian, sampai saat ini, berbagai peraturan perundangundangan, dirasakan masih dihadapkan kepada berbagai kendala, antara lain: terjadi perbedaan penafsiran diantara sesama aparatur penegak hukum, praktisi, teoritisi; perbenturan kepentingan; dis-sinkronisasi antar perundangundangan; dan ketidak jelasan isi peraturan itu sendiri. Hal ini tercermin dari cukup banyaknya kasus sengketa perundang-undangan yang diajukan ke Mahkamah Konstitusi karena bertentangan dengan konstitusi. Disamping itu juga, disinyalir Kementerian Dalam Negeri telah membatalkan cukup banyak Peraturan Daerah (Perda), dan akan menyusul Perda-Perda lainnya. ${ }^{13}$

Pembangunan Hukum merupakan suatu proses yang mencakup komponen-komponen, yakni: materi hukum, aparatur hukum, budaya dan kesadaran hukum masyarakat, sarana dan prasarana hukum. Maka upaya pembinaan terus menerus di sektor aparatur hukum, termasuk dalam hal ini Organisasi Bantuan Hukum yang melakukan penelitian hukum, adalah merupakan salah satu tugas pembangunan Bidang Hukum itu sendiri. Organisasi Bantuan Hukum yang melakukan penelitian hukum, dapat berperan sebagai aparatur pelaksana pembangunan hukum, mempunyai kebutuhan khusus yang pada dasarnya belum dapat tertangani sepenuhnya oleh lembaga formal yang ada. Untuk mewujudkan aparatur peneliti hukum yang baik diperlukan sistem pembinaan yang memadai, antara lain perlu adanya suatu wahana untuk mengembangkan kreativitas para peneliti itu sendiri. Sebab, Organisasi Bantuan Hukum sebagai peneliti dituntut untuk terus berkarya sebagai prasyarat eksistensi dan peningkatan karirnya. Oleh karena itu, wahana penunjang yang dapat membantu pembinaan para peneliti hukum seperti forum-forum ilmiah secara periodik untuk mempresentasikan hasilhasil kajian dan penelitian, penerbitan, jurnal hukum, buletin kegiatan perlu tersedia.

\footnotetext{
12 Idup Suhady dan Desi Fernanda, Dasar-Dasar Good Governance (Jakarta: Lembaga Administrasi Negara-Republik Indonesia, 2005), hlm. 1.

13 http://www.depdagri.go.id.
} 
Antara hukum dan pembangunan terdapat suatu inter-relasi yang erat, dan oleh karenanya setiap proses pembangunan hukum akan mensyaratkan pula terjadinya proses pembangunan hukum. ${ }^{14}$ Proses pembaruan hukum ini hanya akan terselenggara dengan baik apabila dibantu dengan pengkajian dan penelitian permasalahan hukum, yaitu berupa keseluruhan aktivitas berdasarkan disiplin ilmiah untuk mengumpulkan, mengklasifikasi, menganalisis dan menginterpretasikan faktafakta serta hubungan-hubungan di lapangan hukum, yang berdasarkan pengetahuan yang diperoleh dapatlah dikembangkan prinsip-prinsip ilmu pengetahuan dan cara-cara ilmiah untuk menanggapi fakta dan hubungan tersebut. ${ }^{15}$

Pembentukan lembaga-lembaga hukum baru, antara lain: Dewan Komisi Hukum Nasional, Ombudsman, dan lembaga lainnya adalah sebagai pertanda tidak berfungsinya lembaga aparat penegak hukum yang ada saat ini untuk menyelesaikan sengketa yang timbul di dalam masyarakat. Di lain negara pada saat ini dikenal beberapa bentuk lembaga hukum penyelesaian sengketa, yaitu: badan-badan pengadilan, badan-badan arbitrase, badanbadan mediasi dan konsiliasi, mini-trial, dan lain-lain. Lembaga-lembaga pengadilan dan pemutusan perkara (conflict resolution) ini tumbuh, oleh karena asas negara hukum yang terpenting menyatakan bahwa "tiada seorang pun boleh menghakimi perkaranya sendiri". Disamping itu, untuk mendapatkan gambaran yang obyektif dan yang mendekati kebenaran, hakim atau wasit atau mediator, konsiliator, dan lain-lain harus memegang teguh asas audi at alteram partem atau kewajiban untuk juga mendengar pendapat pihak lawan. Itulah sebabnya baik peradilan, badan arbitrase, mediasi atau konsultasi itu menghadirkan "orang

14 Sehubungan dengan hal tersebut diatas, Pasal 19 Undang-Undang Republik Indonesia Nomor 12 Tahun 2011 tentang Pembentukan Peraturan Perundang-Undangan, menegaskan bahwa: (1) Prolegnas sebagaimana dimaksud dalam Pasal 16 memuat program pembentukan Undang-Undang dengan judul Rancangan UndangUndang, materi yang diatur, dan keterkaitannya dengan Peraturan Perundang-undangan lainnya. (2) Materi yang diatur dan keterkaitannya dengan Peraturan Perundang-undangan lainnya sebagaimana dimaksud pada ayat (1) merupakan keterangan mengenai konsepsi Rancangan Undang-Undang yang meliputi: a. latar belakang dan tujuan penyusunan; b. sasaran yang ingin diwujudkan; dan c. jangkauan dan arah pengaturan. (3) Materi yang diatur sebagaimana dimaksud pada ayat (2) yang telah melalui pengkajian dan penyelarasan dituangkan dalam Naskah Akademik. Selanjutnya di dalam Bab V Penyusunan Peraturan Perundang-Undangan Bagian Kesatu Penyusunan Undang-Undang, Pasal 43, menegaskan bahwa: (1) Rancangan Undang-Undang dapat berasal dari DPR atau Presiden. (2) Rancangan Undang-Undang yang berasal dari DPR sebagaimana dimaksud pada ayat (1) dapat berasal dari DPD.(3) Rancangan Undang-Undang yang berasal dari DPR, Presiden, atau DPD harus disertai Naskah Akademik.Pasal 44 (1) Penyusunan Naskah Akademik Rancangan Undang-Undang dilakukan sesuai dengan teknik penyusunan Naskah Akademik. (2) Ketentuan mengenai teknik penyusunan Naskah Akademik sebagaimana dimaksud pada ayat (1) tercantum dalam Lampiran I yang merupakan bagian tidak terpisahkan dari Undang-Undang ini. Selanjutnya, Dalam Lampiran I Undang-Undang Republik Indonesia Nomor 12 Tahun 2011 Tentang Pembentukan Peraturan Perundang-undangan tentang Teknik Penyusunan Naskah Akademik Rancangan Undangundang, Rancangan Peraturan Daerah Provinsi, Dan Rancangan Peraturan Daerah Kabupaten/ Kota, antara lain disebutkan, bahwa: Naskah Akademik adalah naskah hasil penelitian atau pengkajian hukum dan hasil penelitian lainnya terhadap suatu masalah tertentu yang dapat dipertanggungjawabkan secara ilmiah mengenai pengaturan masalah tersebut dalam suatu Rancangan Undang-Undang, Rancangan Peraturan Daerah Provinsi, Rancangan Peraturan Daerah Kabupaten/Kota, sebagai solusi terhadap permasalahan dan kebutuhan hukum masyarakat.

15 Abdurrahman dkk, Beberapa Pemikiran Teuku Mohammad Radhie Tentang Pembaruan Hukum di Indonesia, dalam buku Kumpulan Tulisan Mengenang Teuku Mohammad Radhie (Jakarta: Penerbit Universitas Tarumanagara UPT Penerbitan, 1993), hlm. 58. 
atau fihak ketiga" untuk mendengar keluhan dari kedua pihak, agar dapat memutuskan atau mendamaikan dengan cara sebaik-baiknya.

Hak atas Bantuan Hukum telah diterima secara universal yang dijamin dalam Kovenan Internasional tentang Hak-Hak Sipil dan Politik (International Covenant on Civil and Political Rights (ICCPR)). Pasal 16 dan Pasal 26 ICCPR menjamin semua orang berhak memperoleh perlindungan hukum serta harus dihindarkan dari segala bentuk diskriminasi. Sedangkan Pasal 14 ayat (3) ICCPR, memberikan syarat terkait Bantuan Hukum yaitu: 1) kepentingankepentingan keadilan, dan 2) tidak mampu membayar Advokat. Meskipun Bantuan Hukum tidak secara tegas dinyatakan sebagai tanggung jawab negara namun ketentuan Pasal 1 ayat (3) Undang-Undang Dasar Negara Republik Indonesia Tahun 1945 menegaskan bahwa "Negara Indonesia adalah negara hukum". Dalam negara hukum, negara mengakui dan melindungi hak asasi manusia bagi setiap individu termasuk hak atas Bantuan Hukum.

Penyelenggaraan pemberian Bantuan Hukum kepada warga negara miskin, merupakan upaya untuk memenuhi dan sekaligus sebagai implementasi negara hukum yang mengakui dan melindungi serta menjamin hak asasi warga negara akan kebutuhan akses terhadap keadilan (access to justice) dan kesamaan di hadapan hukum (equality before the law). Jaminan atas hak konstitusional tersebut belum mendapatkan perhatian secara memadai, sehingga dibentuknya Undang-Undang tentang Bantuan Hukum ini menjadi dasar bagi negara untuk menjamin warga negara khususnya bagi orang atau kelompok orang miskin untuk mendapatkan akses keadilan dan kesamaan di hadapan hukum. Oleh karena itu, tanggung jawab negara harus diimplementasikan melalui pembentukan Undang-Undang Bantuan Hukum ini.

Selama ini, pemberian Bantuan Hukum yang dilakukan belum banyak menyentuh orang atau kelompok orang miskin, sehingga mereka kesulitan untuk mengakses keadilan karena terhambat oleh ketidakmampuan mereka untuk mewujudkan hak-hak konstitusional mereka. Pengaturan mengenai pemberian Bantuan Hukum dalam Undang-Undang ini merupakan jaminan terhadap hak-hak konstitusional orang atau kelompok orang miskin. Beberapa pokok materi yang diatur dalam UndangUndang ini antara lain mengenai: pengertian Bantuan Hukum, Penerima Bantuan Hukum, Pemberi Bantuan Hukum, hak dan kewajiban Penerima Bantuan Hukum, syarat dan tata cara permohonan Bantuan Hukum, pendanaan, larangan, dan ketentuan pidana.

Pada Konfrensi pers nya FOKUS (Forum Akses Keadilan untuk Semua (FOKUS) yang terdiri dari LBH Jakarta, LBH APIK, PBHI, ILRC, LBH Pers, Perkumpulan Huma, LBH ASPEK, LKBH FH UNKRIS, LKBH FH UPH, LKBH FH UNPAD, Forum Warga Kota Jakarta (FAKTA), Arus Pelangi, dan Rumah Singgah Master Depok), ${ }^{16}$ memandang terdapat beberapa permasalahan yang krusial dalam implementasi bantuan hukum paska disahkannya Undang-Undang Nomor 16 Tahun 2011 tentang Bantuan Hukum.

\footnotetext{
16 Forum Akses Keadilan untuk Semua (FOKUS) yang terdiri dari LBH Jakarta, LBH APIK, PBHI, ILRC, LBH Pers, Perkumpulan Huma, LBH ASPEK, LKBH FH UNKRIS, LKBH FH UPH, LKBH FH UNPAD, Forum Warga Kota Jakarta (FAKTA), Arus Pelangi, dan Rumah Singgah Master Depok : "Point Krusial Implementasi UU Bantuan Hukum", Jakarta, 2013.
} 
Faktor birokrasi administrasi juga tidak dapat dipandang enteng sebagai salah satu faktor yang ikut andil menghambat terciptanya proses peradilan yang sederhana, cepat dan biaya ringan. Oleh karena itu di samping sebagai penghambat, birokrasi administrasi juga dapat berperan sebagai sumber komersialisasi dan pada akhirnya kembali menjadi komoditi bisnis. Di samping faktor tersebut di atas, proses peradilan yang sederhana, cepat dan biaya ringan juga akan sulit dicapai apabila tidak ada komitmen moral untuk menjadikan pengadilan sebgai rumah keadilan. Kecenderungan untuk mencari "menang" dan "kalah" dalam proses peradilan dapat sebagai petunjuk komitmen terhadap keadilan sudah semakin memudar, dan ini tentunya juga akan berdampak negatif terhadap lajunya proses peradilan.

Begitu rumitnya permasalahan dalam proses peradilan dewasa ini, perlu diupayakan cara yang sekiranya dapat mengatasi faktorfaktor dan kendala penghalang proses peradilan termaksud. Melihat adanya beberapa kelemahan dalam KUHAP dan justru sebagai kunci terhambatnya proses peradilan yang sederhana, cepat dan biaya ringan, maka sudah saatnya diambil tindakan untuk meninjau kembali/merubah ketentuan yang menghambat tersebut. Agar diadakan pembatasan atau seleksi yang ketat terhadap perkara, agar tidak setiap perkara dapat dimintakan banding, kasasi dan peninjauan kembali.Perlu difikirkan agar dalam kasus-kasus tertentu pemeriksaannya langsung ditangani oleh Pengadilan Tinggi tanpa melalui Pengadilan Negeri. Disamping itu, perlu komitmen yang sama dari para aparat peradilan bahwa mereka adalah benar-benar mencari keadilan melalui proses peradilan yang sederhana, cepat dan biaya ringan, sehingga di sini dituntut adanya Supreme of Moral, di samping Supreme of Law.

Menurut Satjipto Rahardjo, 17 hukum dibuat untuk dilaksanakan. Hukum adalah sesuatu yang harus dilaksanakan, sehingga hukum tidak bisa lagi dikatakan sebagai hukum, manakala ia tidak pernah dilaksanakan. Apa yang dijanjikan oleh hukum, pada akhirnya akan menjadi kenyataan melalui manusia-manusia sebagai penegak hukum yang benar-benar menempati kedudukan yang penting dalam proses pelaksanaannya. Akan tetapi kita tidak bisa menutup mata terhadap kenyataan, bahwa para penegak hukum sebagai kategori manusia dan bukan sebagai jabatan, akan cenderung untuk memberikan penafsirannya sendiri terhadap tugas-tugas yang harus dilaksanakannya sesuai dengan tingkat dan jenis pendidikannya, kepribadiannya dan masih banyak faktor lainnya yang berpengaruh.

Suatu pandangan yang hidup dikalangan masyarakat, bahwa hukum itu dijalankan persis sama dengan apa yang tercantum dalam peraturannya; padahal dalam kenyataannya, antara ketentuan hukum yang tercantum dengan pelaksanaannya, terlaluseringterdapatperbedaan dan pada akhirnya selalu mendatangkan masalah. Kata "masalah" dalam Kamus Besar Bahasa Indonesia Menurut Kamus Besar Bahasa Indonesia, ${ }^{18}$ diartikan sebagai sesuatu yang harus diselesaikan atau dipecahkan. Dalam kaitan inilah arti penting suatu pengkajian dan

Satjipto Rahardjo, Masalah Penegakan Hukum, Suatu Tinjauan Sosiologis (Bandung: Penerbit Sinar Baru, 1983), hlm. 5.

18 Tim Penyusun Kamus Pusat Pembinaan \& Pengembangan Bahasa, Kamus Besar Bahasa Indonesia (Jakarta: Departemen Pendidikan dan Kebudayaan, Balai Pustaka, 1991), hlm. 661. 
penelitian hukum yang dilakukan oleh Organisasi Bantuan Hukum dalam rangka pemberian bantuan hukum kepada masyarakat miskin, sangat diperlukan. Pengkajian dan penelitian yang dilakukan oleh Organisasi Bantuan Hukum terhadap fenomena hukum yang melampaui batas-batas pengaturannya disebut sebagai Counter-normative, yang bertolak dari suatu sikap kecurigaan intelektual terhadap hukum. Secara populer, hal ini diutarakan untuk membedakan antara law in the books dan law in action. ${ }^{19}$ Roscoe Pound dalam bukunya Scope and Purpose of Sociological Jurisprudence ${ }^{20}$ mengatakan bahwa studi ilmu hukum tidak hanya berhenti pada mempelajari sistem peraturan perundangundangan, tetapi juga meliputi the actual social effects of legal institutions and legal doctrines; the sociological study in connection with the legal study in preparations for legislation; of making legal rules effective.

Penelitian hukum yang dilakukan Organisasi Bantuan Hukum terhadap efektivitas hukum dalam pelaksanaan pemberian bantuan hukum terhadap masyarakat miskin yang dibiayai oleh negara, adalah suatu contoh yang baik tentang bagaimana hukum itu diamati dalam praktik di tengah-tengah masyarakat, yang pada gilirannya mengundang masuknya aspek-aspek ilmu lain kedalam kajian hukum. Dewasa ini, kajian-kajian ilmu-ilmu sosial semakin banyak memanfaatkan peranan dari ilmu-ilmu sosial dalam mempelajari hukum, antara lain sosiologi, antropologi, psikologi sosial, ekonomi dan lain-lainnya, memiliki akses kedalam studi hukum. Artinya, tidak tertutup kemungkinan bahwa ilmu-ilmu tersebut juga menjadikan hukum sebagai objek kajiannya.
Dari uraian tersebut dapat dikemukakan, bahwa memang perlu memanfaatkan ilmu-ilmu sosial dalam kajian hukum.

Hukum merupakan fenomena yang kompleks dan kompleksitas itu menjadi semakin nyata seirama dengan meningkatnya kompleksitas masyarakat itu sendiri. Oleh karenanya tidak ada satu metodologi saja yang dipakai untuk mempelajari hukum, atau dengan perkataan lain berbagai macam cara untuk mempelajarinya. Salah satu cara yang bisa diterapkan terhadap penelitian hukum oleh Organisasi Bantuan Hukum, adalah cara dan pendekatan sosiologis, disamping penelitian normatif atau doktriner. Berbeda dengan cara pendekatan yang normatifdogmatis yang melihat hukum sebagai suatu keharusan untuk diterima dan diterapkan, maka pengkajian sosiologis lebih melihat hukum sebagai suatu obyek kajian ilmiah yang merupakan kebutuhan masyarakat. Pengkajian secara sosiologis terhadap hukum, merupakan suatu kebutuhan dalam suatu masa dalam masyarakat yang tengah mengalami perubahanperubahan sosial.

Adapun arti penting penelitian permasalahan hukum bagi pembangunan hukum yang dilakukan oleh Organisasi Bantuan Hukum, bahwa dengan melalui kajian ilmiah dibidang hukum, akan dapat mengungkapkan permasalahan-permasalahan yang inheren dalam proses pembangunan hukum, dapat membuat suatu moment opname dari keadaan hukum yang sesungguhnya hidup dalam masyarakat, atau dapat menunjukkan arah kemana sebaiknya hukum dibina berhubung dengan terjadinya perubahan masyarakat sesuai dengan zaman.

19 Ibid, hlm. 6.

20 Rosco Pound, Scope and Purpose of Sociological Jurisprudence, 1912; juga dapat dibaca dalam Satjipto Rahardjo, Ilmu Hukum dan Masyarakat (Bandung, Angkasa, 1980), hlm. 21-22. 
Dalam penelitian permasalahan hukum yang dilakukan oleh Organisasi Bantuan Hukum, harus dapat diindentifikasi berbagai dimensi masalah yang meliputi aspek, antara lain teknologi, sosial, manajerial, politik, ekonomi, agama, hankam dan lain-lain. Dari penelitian tersebut dapat tersimpulkan cara bagaimana, mekanisme apa yang perlu ditingkatkan, atau sarana dan prasarana apa yang diperlukan, dalam kaitannya dengan pelaksanaan pemberian bantuan hukum terhadap masyarakat miskin. Dalam kaitannya dengan pembentukan hukum, maka jika hasil pengkajian menyimpulkan, diperlukan hukum yang baru, maka dilakukan penelitian yang lebih menekankan pada penelitian normatif, yang digabung dengan pendekatan sosio-legal dan perbandingan hukum.

Penelitian ini ditujukan untuk merumuskan norma-norma hukum baru yang telah disarankan oleh pengkajian, dan sekaligus merumuskan alternatif lain. Bahan-bahan yang diperoleh dari penelitian tersebut dapat dijadikan bahan masukan dalam penyusunan Naskah Akademis Peraturan Perundang-undangan (first draft) dari RUU yang hendak disusun. ${ }^{21}$ Badan Pembinaan Hukum Nasional cq Pusat Pembinaan Sistem Hukum Nasional, mempunyai tugas diantaranya melakukan Pengkajian Hukum, Penelitian Hukum dan Menyusun Naskah Akademis Peraturan Perundang-undangan.

Menurut pendapat Andi Hakim Nasution, ${ }^{22}$ mengatakan bahwa penelitian ialah semua usaha untuk menentukan jawaban terhadap suatu permasalahan. Jadi tanpa permasalahan tidak ada atau tidak perlu dilakukan penelitian. Secara singkat dapat dikemukakan beberapa jenis penelitian, antara lain: ${ }^{23}$ Penelitian Murni (pure research) adalah penelitian yang terutama bertujuan untuk pengembangan ilmu pengetahuan. Biasanya penelitian ini dilakukan semata-mata untuk menguji konsep atau teori yang sudah ada, apakah masih valid atau sudah usang karena berbagai kenyataan atau penemuan baru; Penelitian terapan (appleid reseach) adalah penelitian yang hasil-hasilnya dapat secara langsung diterapkan untuk kebutuhan konkrit tertentu, misalnya untuk penyusunan rencana atau program; Penelitian hukum secara murni dapat dilakukan untuk menguji kembali berbagai konsep, dan teori-teori hukum yang ada; Penelitian hukum normatif adalah penelitian terhadap kaidah hukumnya itu sendiri (peraturan perundang-undangan, yurisprudensi, hukum adat atau hukum tidak tertulis lainnya) dan asasasas hukum; dan Penelitian hukum sosiologis adalah penelitian yang mengkaji korelasi antara kaidah hukum dengan lingkungan tempat hukum itu berlaku. Korelasi ini dapat dilihat dalam kaitan pembuatan atau penerapan hukum. Dalam pembuatan hukum, penelitian sosiologis mencoba melihat sajauh mana kaidah hukum yang dibuat tersebut mencerminkan atau tidak mencerminkan kenyataan sosial sebagai sumber material kaidah hukum tersebut.

Munculnya ketidaksepahaman penafsiran perundang-undangan tersebut, menimbulkan permasalahan apakah dalam penyusunan perundang-undangan tersebut telah didukung olehsuatunaskahakademis, argumentasiteoritis, faktual bahkan filosofis, sosiologis dan juridis dalam perumusan konsep-konsep ketika masih dalam RUU. Dukungan Naskah Akademis dalam

21 Tim BPHN, Pola Pikir Kerangka Sistem Hukum Nasional, (Jakarta: BPHN, 1996), hlm. 101.

22 Andi Hakim Nasution, Panduan Berpikir dan Meneliti Secara Ilmiah Bagi Remaja (Jakarta: Gramedia, 1992), hlm. 5.

23 Bagir Manan, Penelitian Terapan Di Bidang Hukum (disampaikan pada Lokakarya di Jakarta, November 1993). 
perancangan RUU dan pembahasan RUU sangat penting. ${ }^{24}$ Setelah semua data diinventarisir dan diidentifikasi kemudian dianalisa lebih lanjut. Tugas analisa ini sangat berat. Data dikaji satu persatu permasalahannya baik dari segi filosofis, historis, sosiologis, dan segi yuridis.. ${ }^{25}$ Dalam ketentuan peralihan ini dicantumkan apabila materi hukum tersebut telah pernah diatur sebelumnya dan diatur kembali. Ketentuan peralihan memuat pemikiran yang menyangkut: Penerapan peraturan perundang-undangan baru terhadap keadaan yang terdapat pada waktu peraturan perundang-undangan mulai berlaku; Bagaimana seharusnya pelaksanaan dari peraturan perundang-undangan yang baru itu; Kemungkinan adanya penyimpangan; Aturan khusus bagi keadaan hubungan yang sudah ada pada saat mulai berlakunya peraturan baru; pemikiran tentang penunjukan organ atau alat perlengkapan negara yang diikutsertakan dalam pelaksanaan peraturan; pemberian nama singkat kepada RUU/RPP; ketentuan tentang saat mulai berlaku; ketentuan tentang pengaruh Undang-undang yang baru terhadap Undangundang yang lain. ${ }^{26}$

Menurut Irawan Soeyitno, bahwa membentuk peraturan perundang-undangan, diperlukan bakat seni tersendiri. Demikian juga pendapat Reed Dickerson seorang Guru Besar Perundang-undangan dari Universitas California,

24 Naskah Akademis Peraturan Perundang-undangan adalah hasil penelitian yang memuat gagasan-gagasan pengaturan suatu materi perundang-undangan (materi hukum) bidang tertentu yang telah ditinjau secara sistemik-holistik-futuristik dan dari berbagai aspek ilmu, dilengkapi dengan referensi yang memuat urgensi, konsepsi, landasan, dan prinsip-prinsip yang digunakan serta pemikiran tentang norma-normanya secara alternatif yang disajikan dalam bentuk uraian yang sistematis. Jadi unsur-unsur suatu Naskah Akademis Peraturan Perundang-undangan yaitu urgensi disusunnya pengaturan baru suatu materi hukum dengan menggambarkan: Hasil inventarisasi hukum positif; dan Hasil identifikasi permasalahan hukum yang dihadapi; Gagasan-gagasan tentang materi hukum yang akan dituangkan kedalam RUU/RPP; Konsepsi landasan dan prinsip yang akan digunakan; Pemikiran tentang norma-normanya, yang dikemukakan secara alternatif; Isi Naskah Akademis Peraturan Perundang-undangan yang sistematis dan disusun Bab demi Bab, untuk memudahkan penggarapan selanjutnya menjadi RUU/RPP.

25 Keabsahan dari suatu undang-undang (Validity of Law), harus memenuhi paling tidak tiga unsur filosofis, sosiologis dan yuridis. Harus memuat penalaran (reasoning) yang menjadi dasar pemikiran mengenai perlunya disusun Naskah Akademis Peraturan Perundang-undangan tersebut. Dasar-dasar pemikiran dapat ditinjau dari landasan, antara lain Filosofis, yaitu pandangan hidup, kesadaran, dan cita-cita hukum serta cita-cita moral yang luhur yang meliputi suasana kewajiban serta watak dari bangsa Indonesia yang didapatkan dalam Pancasila dan Undang-undang Dasar 1945. Yuridis, yaitu sinkronisasi dan harmonisasi, suatu tinjauan terhadap peraturan perundang-undangan yang ada kaitannya dengan peraturan-peraturan yang telah ada dan masih berlaku (hukum positif). Karena untuk dapat menentukan urgensi peraturan yang perlu dibuat terlebih dahulu mengetahui dan memahami: Peraturan mana yang perlu dipertahankan; Peraturan mana yang perlu dicabut; Peraturan mana yang perlu diperbaiki, ditambah atau dikurangi; Aspek-aspek hukum mana yang perlu segera diadakan pengaturan yang baru. Sosiologis, yaitu suatu tinjauan terhadap gejala-gejala sosial-ekonomi-politik yang berkembang di masyarakat yang mendorong perlu dibuatnya undang-undang; serta memuat analisa kecenderungan sosiologisfuturistik sejauh mana tingkah laku sosial itu sejalan dengan arah dan tujuan pembangunan hukum nasional.

26 Sampai saat ini, berdasarkan pengalaman praktek yang dilakukan oleh DPR dan Pemerintah dalam menyiapkan Rancangan Peraturan Perundang-undangan, belum ada keseragaman Naskah Akademik yang dihasilkan. Ketidakseragaman ini berpengaruh pula pada standar hasil suatu Naskah Akademik. Untuk mengantisipasi kebutuhan dan mengatasi persoalan tersebut, perlu disusun suatu Pedoman Penyusunan Naskah Akademik Rancangan Undang-undang. Pedoman ini merupakan hasil akhir dari suatu rangkai diskusi lokakarya dengan mengundang beberapa pakar dan praktisi yang berpengalaman dalam penyusunan Naskah Akademik. Standarisasi penyusunan naskah akademis peraturan perundang-undangan dimaksudkan untuk sebagai pola baku naskah akademis yang diharapkan dapat digunakan sebagai pedoman dalam penyusunan suatu naskah akademis peraturan perundang-undangan. 
mengatakan bahwa "Legislatif drafting is both a science an art". Hal yang sama juga dikemukakan oleh P.M. Bakhsi Guru Besar PerundangUndangan dari India, bahwa "Knowledge of law is inteligence, memory, and judgement, while drafting is skill and art". ${ }^{27}$ Dalam Hyle Morphe, yaitu mengenai bentuk dan materi, ditegaskan bahwa hukum itu terdiri dari peraturan dan keadilan. Bentuk dapat berubah-ubah, namun materi tidak dapat berubah. Begitu juga dengan hukum, bentuknya dapat berubah-ubah, namun keadilan yang merupakan materi hukum tidak dapat diubah. Hukum yang tidak memuat keadilan, adalah tidak bermakna, karena kata kunci dalam hukum bukanlah kepastian, akan tetapi adalah keadilan.

Fenomena sosial menunjukkan bahwa penyelesaian silang sengketa permasalahan hukum dewasa ini, banyak dikeluhkan masyarakat yang kadang-kadang mengkristal menjadi suatu sikap dan perilaku reaksional yang sangat merugikan wibawa hukum. Atensitas masyarakat terhadap hukum, bermuara kepada peradilan sebagai katup penekan atau pressure valve atas segala pelanggaran konstitusi. Peradilan diharapkan dapat berperan sebagai the last resort yakni sebagai tempat terakhir mencari kebenaran konstitusi dalam kaitannya dengan berbangsa dan bernegara, sehingga dapat diandalkan sebagai lembaga penegakkan kebenaran dan keadilan (to enforce the truth and to enforce justice).

Suatu mitos yang berkembang dikalangan masyarakat, bahwa penegakan hukum terkait dengan kasus politik yang dipengaruhi oleh kekuatan ekstra yudisional. Sementara proses dan perkara non-politik, dipengaruhi oleh godaan materi. Terlepas dari benar-tidaknya anggapan itu, akan mempengaruhi citra, wibawa dan kredibilitas hukum. Dewasa ini, keraguan, skeptisme, serta merosotnya tingkat kepercayaan masyarakat terhadap hukum yang hampir mencapai titik nadir, baik terhadap aparatur, materi maupun lembaga penegakan hukum. Halini disebabkan perundang-undangan sering telah menjadi alat kekuasaan yang pelaksanaannya diselewengkan sedemikian rupa sehingga bertentangan dengan prinsip demokrasi dan keadilan, persamaan hak warga negara di mata hukum. Pembuatan suatu undang-undang sangat kental dipengaruhi oleh muatan politis, hukum dipakai sebagai alat untuk mengabsahkan tindakan penguasa. ${ }^{28}$

\section{Peran Penelitian Hukum Yang Dilak- sanakan Oleh Organisasi Bantuan Hukum}

Organisasi Bantuan Hukum sebagai peneliti hukum juga sangat berperan dalam pengumpulan dan analisis tentang kesadaran masyarakat 
terhadap hukum, sebab kesadaran hukum yang makin meningkat dapat menyebabkan meningkatnya tuntutan masyarakat terhadap perangkat hukum yang dapat memberikan kepastian dan pengayoman hukum yang berintikan keadilan dan kebenaran. Bahkan tingginya kesadaran hukum dapat pula menyebabkan masyarakat menjadi semakin kritis dalam menanggapi permasalahan yang berkaitan dengan hukum. Akibatnya tuntutan akan keadilan makin meluas. Apabila tuntutan tersebut tidak terpenuhi baik secara formal maupun materil kadang kala dapat mengakibatkan sikap sebagian masyarakat menjadi kurang menghargai hukum.

Hal demikian merupakan fenomena yang tidak sederhana yang memerlukan penelitian secara mendalam. Oleh karena itu diperlukan pengembangan metoda-metoda penelitian hukum yang dapat menjaring data yang sangat mendasar. Misalnya timbulnya gejala-gejala konflik sosial mungkin saja diakibatkan oleh kurangnya kesadaran hukum masyarakat atau mungkin juga diakibatkan oleh adanya tindakan aparatur negara yang mencerminkan kurangnya penghayatan terhadap hukum. Hukum sesungguhnya tidaklah semata-mata ditujukan kepada masyarakat, namun ditujukan pula kepada setiap penyelenggara negara, khususnya dalam melaksanakan fungsinya untuk memberikan pelayanan kepada masyarakat. Dalam hal ini peranan penelitian juga sangat penting dalam upaya mengembangkan kesadaran dan ketaatan hukum serta disiplin nasional yang merupakan perwujudan kepatuhan dan ketaatan kepada hukum dan norma yang berlaku dalam masyarakat.

Paradigma pembangunan hukum nasional yang dilakukan pada saat ini dan masa yang akan datang, memandang hukum tidak hanya sebagai obyek, tapi juga menjadi subyek pembangunan.
Materi hukum (UU pada khususnya) dipandang tidak lagi sebagai instrumen penjaga keamanan, ketertiban, dan keadilan belaka, tapi sekaligus sebagai instrumen perubahan masyarakat, alat transformasi nilai dari bentuk tertentu ke dalam wujud dan bentuk nilai lain yang lebih baik. Visi pembangunan hukum nasional yang demikian menuntut terjadinya perubahan penanganan pembinaan hasil-hasil penelitian hukum. Perubahan ini hendaknya diarahkan pada pengadaan peneliti hukum yang tidak saja memiliki kemampuan, perhatian yang cukup, terdidik dan terlatih dengan baik, tapi juga diangkat dan diberi tunjangan dan fasilitas serta penghargaan yang memadai sebagai aparat peneliti hukum sebagaimana mestinya.

Perlu untuk dikembangkan gagasan mengenai kualitas pemberian keadilan (the dispension of justice) yang lebih cocok dengan sistem hukum Pancasila. Menata dan membangun kesadaran serta perilaku hukum adalah membangun kehidupan moral bangsa secara keseluruhan, yang tidak bisa menunggu sampai kesejahteraan hidup meningkat secara substansial. Rendahnya kesadaran hukum di Indonesia tidak hanya dimiliki oleh rakyat saja, akan tetapi juga oleh penguasa. Lemahnya kesadaran hukum di Indonesia antara lain disebabkan; kurangnya kepastian yang diberikan oleh hukum yang berlaku; adanya perlakuan yang berbeda terhadap warga masyarakat; masih lemahnya komitmen dari pihak penguasa dalam pelaksanaan hukum dalam masyarakat. Perbedaan perilaku hukum yang timbul dalam masyarakat tidak hanya dipengaruhi oleh hukum saja, akan tetapi juga oleh faktor-faktor lain, seperti pendidikan dan agama. Untuk berlakunya hukum dalam masyarakat tidak saja diperlukan landasan yang bersifat yuridis dan filosofis tetapi juga suatu landasan yang bersifat 
sosiologis, sehingga hukum itu mempunyai wibawa berlaku dalam masyarakat.

Yurisprudensi merupakan kebutuhan yang fundamental untuk melengkapi pelbagai peraturan perundang-undangan dalam penerapan hukum, karena dalam sistem hukum nasional memegang peranan sebagai sumber hukum. Tanpa yurisprudensi fungsi dan kewenangan peradilan sebagai pelaksanaan kekuasaan kehakiman, dapat mengalami kemandulan dan stagnasi. ${ }^{29}$

Aparat hukum (dalam arti luas) adalah pelaksana tugas penelitian, pembentukan, pelayanan hukum yang menghasilkan tindakantindakan maupun penegakan hukum yang menimbulkan akibat hukum baik secara faktual maupun dalam bentuk keputusankeputusan hukum dan pelayanan/bantuan hukum lainnya. Aparat hukum terdiri dari aparat hukum dalam lingkup penyelenggaraan tugas administrasi negara dan di luar lingkup tersebut. Sistem pendidikan bagi aparat hukum perlu diorientasikan pada kematangan dan kemampuan profesionalisme. Disamping itu, perlu ditingkatkan fungsi pengawasan bagi aparat penegak hukum dan tindakan tegas terhadap segala penyimpangan. Manajemen Hukum meliputi hal-hal di bidang penelitian, pembentukan, peradilan, penerapan dan penegakan hukum, penyuluhan hukum, pelayanan dan bantuan hukum, pendidikan dan latihan aparat hukum. Dalam pembinaan peradilan yang masih perlu penyempurnaan adalah dalam bidang organisasi, landasan acara, kebebasan hakim, pelaksanaan putusan, hubungan dan koordinasi antar lembaga penegak hukum, dayaguna pemeriksaan perkara dan pemantapan yurisprudensi sebagai salah satu sumber hukum. Dalam bidang penerapan dan penegakan hukum yang masih perlu ditingkatkan adalah peran lembaga-lembaga penegakan hukum non pemerintah, antara lain lembaga arbitrase, Organisasi bantuan hukum, lembaga konsiliasi.

Dalam rangka pelaksanaan reformasi, program pembangunan bidang hukum sangat dibutuhkan untuk mengatur kehidupan berbangsa dan bernegara yang tertib teratur dan berkeadilan, disamping melindungi berbagai aspek hak asasi manusia. Oleh karena itu, langkah-langkah strategis perlu ditempuh untuk meningkatkan akselerasi reformasi hukum, yang mencakup 4 
(empat) aspek, yaitu: (a) aspek legislasi, (b) aspek sumberdaya manusia, (c) aspek kelembagaan dan infrastruktur, dan (d) aspek budaya hukum. ${ }^{30}$ Aspek-aspek pembangunan hukum nasional tersebut merupakan faktor yang menentukan keberhasilan kebijakan pemerintah dalam menegakkan keadilan dan hak asasi manusia. Ke empat aspek tersebut juga merupakan hal penting dalam memecahkan persoalan-persoalan mendasar dalam bidang hukum yang mencakup perencanaan hukum (legislation planning), proses pembuatan hukum (law making process), penegakan hukum (law enforcement) dan pembinaan kesadaran hukum (law awareness). ${ }^{31}$

Untuk lebih memantapkan tugas dan fungsi lembaga-lembaga peneliti hukum, dimasa mendatang perlu : dikembangkan forum komunikasi antara Badan Pembinaan Hukum Nasional, Kementerian Hukum dan HAM-RI dengan Organisasi Bantuan Hukum, lembaga penegak hukum, pelayanan hukum, dan profesi hukum dalam suasana kebersamaan dengan prinsip saling mempercayai dan menghormati kedudukan masing-masing; mengembangkan pendidikan dan latihan bersama untuk semua lembaga penegak hukum agar ada kesamaan persepsi di bidang peradilan dan penegakan hukum. BPHN sebagai suatu badan/lembaga yang bertugas melakukan pembinaan hukum nasional, berarti tidak saja hanya melakukan pembinaan terhadap hukum tertulis (Peraturan Perundang-undangan), akan tetapi juga meliputi pembinaan terhadap budaya hukum, lembaga, serta aparatur hukum (SDM) yang masing- masing harus ditunjang oleh segala sarana dan prasarana fisik dan nonfisik yang memadai. ${ }^{32}$

Pengembangan koordinasi dan kerjasama ini didasarkan pada kenyataan adanya tuntutan kapasitas dan kapabilitas sebagai aparat peneliti di satu sisi dan kendala pembinaan hukum yang belum tertangani secara efektif dan efisien di sisi lainnya.Dalam kaitan tersebut, perlu dibangun, dibentuk suatu wadah, organisasi untuk berhimpun para peneliti hukum di Indonesia didalam suatu Ikatan Peneliti Hukum Indonesia (IPHI). Pembentukan organisasi ini, dimulai dari daerah-daerah ditingkat propinsi (IPHD), yang kemudian akan berpuncak pada pelaksanaan Musyawarah Nasional Peneliti Hukum di Jakarta, yang diikuti oleh para ketua dan sekretaris Ikatan Peneliti Hukum Propinsi.

\section{E. Penutup}

\section{Kesimpulan}

Bertitik tolak dari uraian tersebut diatas, maka pada bagian akhir dari peneltian ini, dikemukakan disimpulkan bahwa Peranan Penelitian Hukum yang dilakukan oleh Organisasi Bantuan Hukum sebagai implementasi Pasal 9c Undang-Undang Nomor 16 Tahun 2011 tentang Bantuan Hukum, sangat penting dalam mendukung pembangunan Sistem Hukum Nasional, untuk mengungkapkan datailmiahyangmenyangkutaspek-aspekfilosofis, yuridis, sosiologi, ekonomi, maupun politik yang dapat mempengaruhi perkembangan hukum sebagai bahan kebijaksanaan pembangunan hukum. Sebab banyak hasil-hasil penelitian hukum yang dilakukan oleh berbagai lembaga

\footnotetext{
30 Biro Hubungan Masyarakat dan Luar Negeri, Implementasi Tugas Pembangunan, Penerapan Hukum dan HAM (Jakarta: Departemen Kehakiman dan HAM RI, 2003), hlm. 184-186.

31 Majalah Hukum Nasional, No. 2, (2001): 2.

32 Badan Pembinaan Hukum Nasional, Departemen Kehakiman-RI, Pola Pikir dan Kerangka Sistem Hukum Nasional (Jakarta: BPHN, 1995/1996), hlm. 39-49.
} 
penelitian hukum didaerah, tidak sepenuhnya terakumulasi dalam penentuan kebijakan hukum di pusat sesuai dengan semangat otonomi daerah.

Dalam rangka pelaksanaan penelitian hukum dalam kaitannya dengan pelaksanaan pemberian bantuan hukum, beberapa hal yang dapat menimbulkan permasalahan, adalah: Limitasi Penerima Bantuan Hukum yang hanya terbatas pada masyarakat tidak mampu; Kewenangan tanpa Batas Penyelenggara Bantuan Hukum; Permasalahan Verifikasi dan Akreditasi; Permasalahan Pemberi Bantuan Hukum yang seakan-akan dimonopoli Advokat; Prosedur Mendapatkan Bantuan Hukum.

\section{Saran}

Bertitik tolak dari uraian tersebut diatas, dapat dikemukakan beberapa saran/ rekomendasi, antara lain bahwa dalam pelaksanaan kegiatan penelitian hukum yang dilakukan oleh organisasi bantuan hukum untuk kepentingan pemberian bantuan hukum, maka perlu dikembangkan penelitian terapan yang normatif dan interdisipliner dalam mendukung penetapan kebijaksanaan dan pengambilan keputusan dalam rangka pelaksanaan bantuan hukum dan pembangunan hukum nasional, serta penyempurnaan dan pemantapankerja sama penelitian dan pengembangan hukum dengan berbagai instansi termasuk Organisasi Bantuan Hukum dan perguruan tinggi serta lembaga penelitian nasional, maupun internasional.

Perlu dilakukan Penelitian tentang permasalahan-permasalahan: Limitasi Penerima Bantuan Hukum yang hanya terbatas pada masyarakat tidak mampu; Kewenangan tanpa Batas Penyelenggara Bantuan Hukum; Permasalahan Verifikasi dan Akreditasi; Permasalahan Pemberi Bantuan Hukum yang seakan-akan dimonopoli Advokat; Prosedur Mendapatkan Bantuan Hukum.

Perlu mengembangkan forum pertemuan ilmiah secara periodik diantara para peneliti hukum antara pusat dan daerah dalam rangka pemanfaatan hasil-hasil penelitian hukum baik ditingkat pusat maupun di daerah. Seperti, membina koordinasi dan kerja sama dengan wadah Ikatan Peneliti Hukum Indonesia (IPHI), untuk pengembangan dan pemanfaatan hasil penelitian hukum antar berbagai instansi baik di pusat maupun di daerah, kalangan akademis, lembaga pengkajian dan penelitian hukum, organisasi profesi dan organisasi kemasyarakatan lainnya. Mengupayakan kondisi profesi fungsional peneliti hukum menjadi lebih menarik, agar minat para professional pengacara, advokat, juga bergairah menjadi peneliti hukum.

\section{DAFTAR PUSTAKA}

\section{Buku}

Badan Pembinaan Hukum Nasional, Departemen Kehakiman-RI, Pola Pikir dan Kerangka Sistem Hukum Nasional (Jakarta: BPHN, 1995/1996).

Badan Pembinaan Hukum Nasional, Rencana dan strategi Pembangunan Hukum Nasional Tahun 2005 - 2009, (Jakarta: Badan Pembinaan Hukum Nasional, 2005).

Biro Hubungan Masyarakat dan Luar Negeri, Implementasi Tugas Pembangunan, Penerapan Hukum dan HAM (Jakarta: Departemen Kehakiman dan HAM RI, 2003).

Hariningsih, Sri, Proses dan Teknik Penyusunan Peraturan Perundang-undangan Khususnya Peraturan Daerah (Jakarta: BPHN, 2003).

Jennings, Sir Ivor, The Cabinet Government (New York, USA: West Publishing Company, 1990).

M. Friedmann, Lawrennt, Rivival of Natural Law Theories (New York: NY Publishers, 1953).

Marryman, John Henry, The Civil Law Tradition (Standford: California Press, 1969).

Moore, Narrington, The Social Origins of Divtatorschip and Democracy. Lord and Peasant in the Making of Modern World (Boston: Beacon, 1966). 
Myrdal, Penelitian Terhadap Hukum Negara Berkembang (Jakarta: Pradnya Paramita, 1971).

Nasution, Andi Hakim, Panduan Berpikir dan Meneliti Secara Ilmiah Bagi Remaja, (Jakarta: Gramedia, 1992).

Nonet \& Selznick, Law and Society in Trantition, (New York: Harper Colophon Books, 1978).

Rahardjo, Satjipto, Ilmu Hukum dan Masyarakat (Bandung, Angkasa, 1980).

Rahardjo, Satjipto, Masalah Penegakan Hukum, Suatu Tinjauan Sosiologis (Bandung: Penerbit Sinar Baru, 1983).

Rahardjo, Satjipto, IImu Hukum dan Masyarakat (Bandung, Angkasa, 1980).

Soekanto, Soerjono \& Sri Mamudji, Penelitian Hukum Normatif Suatu Tinjauan Singkat (Jakarta: CV.Rajawali, 1985)

Soekanto, Soerjono, Pengantar Penelitian Hukum (Jakarta: Universitas Indonesia, 1986).

Strong, C.F., Modern Political Constitutions, (Little Essex Street London WC2: Mac Millan And Company Limited, 1961).

Suhady, Idup dan Desi Fernanda, Dasar-Dasar Good Governance (Jakarta: Lembaga Administrasi Negara-Republik Indonesia, 2005).

Teubner, Gunther, Substantive and Reflexive Elements in Modern Law, Law and Society Review, (London: London Press, 1983).
Tim Penyusun Kamus Pusat Pembinaan \& Pengembangan Bahasa, Kamus Besar Bahasa Indonesia (Jakarta: Departemen Pendidikan dan Kebudayaan - Balai Pustaka, 1991).

VanderVlies, Inge C, Hand Boek Wetgeving, (California: USA Press, 1987).

\section{Makalah / Artikel / Prosiding / Hasil Penelitian}

Forum Akses Keadilan untuk Semua (FOKUS) yang terdiri dari LBH Jakarta, LBH APIK, PBHI, ILRC, LBH Pers, Perkumpulan Huma, LBH ASPEK, LKBH FH UNKRIS, LKBH FH UPH, LKBH FH UNPAD, Forum Warga Kota Jakarta (FAKTA), Arus Pelangi, dan Rumah Singgah Master Depok : "Point Krusial Implementasi UU Bantuan Hukum", Jakarta, 2013.

Haramain ,Malik \& Hakam Naja, "Gabung Lembaga Serupa", Kompas, Jumat, 18 Nopember 2011.

Majalah Hukum Nasional, No. 2, (2001).

Manan, Bagir, "Penelitian terapan Di Bidang Hukum" (makalah disampaikan pada Lokakarya, di Jakarta, November 1993).

\section{Internet}

http://www.depdagri.go.id. 